\title{
Growth Performance of Single Comb White Leghorn Chicks Fed Diets Containing Blood Meal Supplemented with Isoleucine
}

\author{
James Tyus II, Samuel N. Nahashon, Nathaniel Adefope and Darren Wright \\ Institute of Agricultural and Environmental Research, Tennessee State University, \\ 3500 John A. Merritt Blvd., Nashville, Tennessee 37209-1561, USA
}

\begin{abstract}
The suitability of blood meal supplemented with isoleucine as protein source for Single Comb White Leghorn (SCWL) chicks was evaluated. In four replicates, four hundred and eighty SCWL chicks were fed diets containing blood meal with supplemental isoleucine from day-old to 10 weeks of age (WOA). The experimental diets were corn-based with the protein sources being $100 \%$ soybean meal (control), $100 \%$ blood meal (BM), $50 \%$ soybean meal $+50 \%$ blood meal (SMBM), and $50 \%$ alfalfa meal $+50 \%$ blood meal (AMBM). Blood meal comprised $16.8 \%, 11.0 \%$ and $14.3 \%$ of the total ration in $\mathrm{BM}$, SMBM, and AMBM diets, respectively. Experimental birds were provided a $23 \mathrm{hr}$ light regimen and feed and water were provided at free choice. Feed consumption (FC) and body weights (BW), from which feed conversion ratios (FCR) and body weight gains (BWG) were calculated, were measured weekly. Shank lengths (SL) were measured weekly and mortality was recorded as it occurred. Birds fed the BM diet exhibited significantly lower $(P<0.05)$ FC, BWG and SL than those on other dietary treatments. Birds fed SMBM were $14 \%$ and $8 \%$ heavier, consumed $12 \%$ and $11 \%$ more feed and had $5 \%$ lower FCR than those fed BM and AMBM diets, respectively. Percent mortality was highest $(P<0.05)$ in birds fed the BM diet when compared with those in other dietary treatments such that BM $>$ SMBM $>$ AMBM $>$ Control. Based on this study, substitution of up to 50 percent of soybean meal with blood meal supplemented with isoleucine in corn-soy based diets did not adversely affect growth performance of SCWL chicks from day-old to 10 WOA.
\end{abstract}

Key words: blood meal, body weight gain, feed consumption, feed conversion, Single Comb White Leghorn

J. Poult. Sci., 45: 31-38, 2008

\section{Introduction}

Within the poultry industry, $75-80$ percent of the total cost of production is attributed to feeding costs. Of this, nearly thirty percent is due to supplying protein in rations (Coon, 2002). Protein is the single most expensive nutrient in diets of most livestock (National Research Council, 1994). Soybean meal is the most common source of protein in poultry rations in many parts of the world. However, in areas where soybean crop does not thrive well, dependence on imported soybean or soybean meal can be quite costly and translates into high costs of poultry production. Alternative sources of protein must therefore be sought.

Various feed ingredients have been evaluated for their suitability as protein sources in poultry diets. For example, Costa et al. (2001) fed peanut meal as a protein source for broiler chickens. Addition of threonine to a cornpeanut meal-based (PNM) diet increased body weight gain and decreased feed conversion ratio. Technical per-

Received: May 9, 2007, Accepted: September 19, 2007

Correspondence: Dr. S.N. Nahashon, Institute of Agricultural \& Environmental Research, Tennessee State University, 3500 John A. Merritt Blvd., Nashville, TN 37209-1561, USA.

(E-mail: Snahashon@tnstate.edu) formance of birds fed PNM was similar to soybean meal (SBM) at the highest protein levels fed. This led to the conclusion that PNM could be used as a protein source for broilers under appropriate economic conditions. Sterling et al. (2002) evaluated the partial substitution of cottonseed meal in corn-soy based diets of broiler chickens. Their study showed that at slightly higher protein levels cotton seed meal could replace soybean meal in broiler grower diets to achieve similar performance.

Other studies have also shown that although certain feed ingredients that may be useful sources of animal protein may lack some essential amino acids whose deficiency in poultry rations could result in poor bird performance. Supplementing these diets with the deficient amino acids has shown significant improvement in bird performance. Kita et al. (2002) evaluated the influence of dietary protein source [isolated soybean protein vs. casein; crude protein (CP) 20\%] and the supplementation of essential amino acids on Insulin-Like Growth Factor Binding Protein-2 (IGFBP-2) expression of young chickens (5 wk old). Feeding the low protein diet without supplemental amino acids for $7 \mathrm{~d}$ decreased brain IGFBP- 2 mRNA level and increased gizzard IGFBP-2 levels.

Blood meal, a by-product of animal rendering is also an alternative protein source in the animal production enterprise because it is readily available in many parts of the 
world. Because it is typically manufactured, on-site, at slaughter houses, blood meal can be made commercially available as animal feed all year-round. Blood meal contains about 80 to 88 percent crude proteins (CP) compared to about 48 percent $\mathrm{CP}$ in soybean meal. It has a minimum biological availability of 80 percent based on the species studied, feeding regimen, housing conditions and other environmental factors (Hoaglund et al., 1992; Sindt et al., 1993; and Kats et al., 1994). The NRC (1994) reports methionine and lysine digestibility coefficients of about 90 percent while cysteine and isoleucine figures are both below 80 percent.

Isoleucine is the primary limiting amino acid in blood meal (less than $1 \%$ on dry-matter basis). Isoleucine is a branched-chain, aliphatic essential amino acid. It is an isomer of leucine and is important in hemoglobin synthesis and regulation of blood sugar and energy levels. Deficiency has been shown to lead to fatal malformation of blood clots and, in extreme cases, lowered immune responses in chickens (Hale et al., 2004). Weight gain of broilers has also been shown to decrease as dietary concentrations of dietary isoleucine decreased (Burnham et al., 1992). Kidd et al. (2004) reported that supplementing broiler rations with isoleucine also yields better feed conversion ratios and carcass response. Thus, the primary objective of this study was to evaluate the suitability of blood meal with supplemental isoleucine (S-Ile) as a protein source for growing Single Comb White Leghorn (SCWL) chicks. The effect of partial substitution of alfalfa meal for blood meal in the rations of SCWL chicks was also evaluated. Alfalfa meal is a readily available, high protein, high fiber animal feedstuff (Garcia et al., 2000; Sibbald, 1979). A1falfa is well balanced in amino acids and rich in vitamins, carotenoids, and xanthophylls that give poultry carcasses their desirable yellow color (Ponte et al., 2004). Alfalfa also contains high levels (2-3\% of DM) of saponins which have been shown to have antioxidant and antiinflammatory properties (Klita et al., 1996; Ponte et al., 2004). In addition, alfalfa is greatly advantageous in poultry rations due to its fermentation properties by cecal microflora that are capable of limiting growth of pathogenic microorganisms in the gastrointestinal tract of laying hens (Donalson et al., 2004). Alfalfa, with its high fiber content, has been shown to have a very long transit time in the gastrointestinal tract of chickens. The increase in transit time favors bacterial degradation of dietary fiber into fermentable substrates such as fructooligosaccharides to short chain fatty acids. These actions help maintain the small and large intestine by increasing mucosal structure and function as well as increasing the commensal bacteria in the gastrointestinal tract (Salvin et al., 1985; Buddington et al., 1999). Therefore, it is expected that inclusion of alfalfa meal in diets of SCWL chicks containing blood meal would enhance bird performance.

\section{Materials and Methods}

\section{Birds and Management}

Four hundred and eighty day-old Hyline Single Comb White Leghorn (SCWL) chicks (Hyline International, Warren IN) were used in this study. Birds were wing banded, weighed, and one hundred and twenty birds were assigned to each one of four dietary treatments in a completely randomized experimental design. Birds were housed in Petersime ${ }^{\mathrm{TM}}$ (Petersime Incubator Company, Gettysburg, $\mathrm{OH}$ ) battery brooders and a constant temperature of $32.2^{\circ} \mathrm{C}$ was maintained for the first week of age (WOA). The temperature was decreased by $2.8^{\circ} \mathrm{C}$ each subsequent week until a temperature of $21.1^{\circ} \mathrm{C}$ was attained. At that point (approximately 4 WOA), no supplementary heating was provided. The battery cages measured $99 \times 66 \times 26 \mathrm{~cm}$ and each housed 15 birds. At five WOA the chicks were transferred into growing batteries which were not supplied with supplemental heating. However constant room temperature was maintained at 21.1 ${ }^{\circ} \mathrm{C}$. The growing cages measured $163 \times 69 \times 33 \mathrm{~cm}$ and each housed seven to eight birds from five to ten WOA. Both feed and water were administered ad libitum and a 23-hour light regimen was used. Ventilation within the growing cages was maintained by thermostatically controlled exhaust fans.

\section{Dietary Treatments}

The composition of experimental diets fed to SCWL chicks from day-old to 10 WOA are presented in Table 1. The experimental diets were isocaloric and isonitrogeneous and contained 2,900 kcal metabolizable energy (ME) $/ \mathrm{kg}$ diet and $20 \%$ crude protein (CP). Dietary treatments were, where deficient, supplemented with isoleucine, especially those containing blood meal. The experimental diets were corn-based with the protein sources being 100\% soybean meal (control), 100\% blood meal (BM), 50\% soybean meal $+50 \%$ blood meal (SMBM) and $50 \%$ alfalfa meal $+50 \%$ blood meal (AMBM). Blood meal comprised $16.8 \%, 11.0 \%$ and $14.3 \%$ of the total ration in BM, SMBM, and AMBM diets, respectively. Each treatment was replicated four times.

\section{Evaluation of Growth Performance}

Growth performance was evaluated, primarily, on the basis of body weight gain (BWG) and feed conversion ratios (FCR). Body weight and feed consumption were measured weekly from hatch to sixteen WOA. Feed conversion ratio was calculated by dividing weekly feed consumption by weekly body weight gain for each replicate. The shank lengths of approximately $17 \%$ of the experimental birds in each treatment group were measured weekly at 6 to $10 \mathrm{WOA}$. At ten WOA, $10 \%$ of experimental birds from each replicate were randomly selected and weighed individually. Feed was withdrawn from the birds overnight and the birds were euthanatized by hand using a conventional unilateral neck cut to sever the carotid artery and jugular vein and bled for $180 \mathrm{~s}$. Internal organs which include the heart, kidney, liver, lungs, pancreas, and 
Table 1. Composition of diets fed to Single Comb White Leghorn chicks from day-old to ten weeks of age, $\%$

\begin{tabular}{|c|c|c|c|c|}
\hline & \multicolumn{4}{|c|}{ Dietary Treatment } \\
\hline & Corn-Soy & BM & SMBM & AMBM \\
\hline & \multicolumn{4}{|c|}{ Percent of protein source(s) in diet } \\
\hline Soybean meal & 100 & 0 & 50 & 0 \\
\hline Blood Meal & 0 & 100 & 50 & 50 \\
\hline Alfalfa meal & 0 & 0 & 0 & 50 \\
\hline \multicolumn{5}{|l|}{ Feed Ingredient } \\
\hline Corn $(8 \% \mathrm{CP})$ & 60.3 & 71.9 & 69 & 66.49 \\
\hline Soybean meal (44\% CP) & 35.3 & 0 & 11.2 & 0 \\
\hline Alfalfa meal $(17 \% \mathrm{CP})$ & 0 & 0 & 0 & 14.4 \\
\hline Blood meal $(80 \% \mathrm{CP})^{1}$ & 0 & 16.8 & 11.2 & 14.4 \\
\hline Poultry Blended Fat & 0.4 & 0.3 & 0 & 1.15 \\
\hline Dicalcium Phosphate (18\% P, $22 \% \mathrm{Ca})$ & 1 & 1.55 & 1.5 & 1.4 \\
\hline Limestone Flour $(38.8 \% \mathrm{Ca})$ & 1.5 & 1.12 & 1.2 & 0.75 \\
\hline Isoleucine & 0 & 0.64 & 0.45 & 0.59 \\
\hline Salt & 0.37 & 0.37 & 0.37 & 0.37 \\
\hline Vitamin-Mineral Premix ${ }^{1,2}$ & 0.25 & 0.25 & 0.25 & 0.25 \\
\hline D,L-Methionine $(98 \%)^{3}$ & 0.11 & 0.21 & 0.18 & 0.2 \\
\hline Sand & 0.77 & 6.86 & 4.65 & 0 \\
\hline \multicolumn{5}{|l|}{ Calculated analyses } \\
\hline Crude Protein, $\%$ & 20.08 & 20.03 & 20.01 & 20.01 \\
\hline $\mathrm{ME}$ (Kcal/kg diet) & 2901.6 & 2907.2 & 2903.3 & 2901.5 \\
\hline Calcium, $\%$ & 0.94 & 0.90 & 0.92 & 0.92 \\
\hline Phosphorus, \% & 0.33 & 0.41 & 0.41 & 0.40 \\
\hline Cysteine, \% & 0.35 & 0.22 & 0.26 & 0.22 \\
\hline Methionine, $\%$ & 0.44 & 0.43 & 0.44 & 0.43 \\
\hline Lysine, \% & 1.17 & 1.37 & 1.30 & 1.29 \\
\hline Isoleucine, $\%$ & 1.00 & 1.00 & 1.02 & 1.01 \\
\hline Crude fat, $\%$ & 2.97 & 3.03 & 2.71 & 4.04 \\
\hline \multicolumn{5}{|l|}{ Analyzed levels } \\
\hline $\mathrm{CP}$ & 19.92 & 19.91 & 19.79 & 19.89 \\
\hline Crude Fat & 2.87 & 2.93 & 2.63 & 3.94 \\
\hline
\end{tabular}

\footnotetext{
${ }^{1}$ Animal Health \& Nutrition, Nashville, TN.

${ }^{2}$ Provided per kg of diet: retinyl acetate, 3,500 IU; cholecalciferol, 1,000 ICU; DL- $\alpha$-tocopheryl acetate, 4.5 IU; menadione sodium bisulfite complex, $2.8 \mathrm{mg}$; vitamin $\mathrm{B}_{12}, 5.0 \mathrm{mg}$; riboflavin, $2.5 \mathrm{mg}$; pantothenic acid, 4.0 $\mathrm{mg}$; niacin, $15.0 \mathrm{mg}$; choline, $172 \mathrm{mg}$; folic acid, $230 \mathrm{mg}$; ethoxyquin, $56.7 \mathrm{mg}$; manganese, $65 \mathrm{mg}$; iodine, $1 \mathrm{mg}$; iron, $54.8 \mathrm{mg}$; copper, $6 \mathrm{mg}$; zinc, $55 \mathrm{mg}$; selenium, $0.3 \mathrm{mg}$.

${ }^{3}$ Degussa Corporation, Kennesaw, GA.
}

spleen were harvested, blotted dry and weighed. The digestive tracts were washed with distilled water to remove digesta, blotted dry with paper towel and weighed. Mortality was recorded as it occurred.

\section{Statistical Analysis}

Data were analyzed by the ANOVA option of the general linear model of SAS/STAT software SAS ${ }^{\circledR}$ (SAS Institute, 2002) as completely randomized design with dietary treatments as main effects. The statistical model used was: $Y_{\mathrm{ijk}}=\mu+T_{\mathrm{i}}+\mathbf{R}_{\mathrm{ij}}+\gamma_{\mathrm{ijk}}$, where $\mathrm{Y}_{\mathrm{ijk}}=$ response variables from each individual replication, $\mu=$ the overall mean; $T_{i}=$ the effect of dietary treatments; $R_{i j}=$ the interexperimental unit (replications) error term; and $\gamma_{\mathrm{ijk}}=$ the intra-experimental unit error term. Least significant difference comparisons were made between treatment means for main effects when there was a significant F-value. Differences in mortality among dietary treatments were analyzed using the chi-square method. Significance implies $(P<0.05)$ unless stated otherwise.

\section{Results and Discussion}

Average weekly and total feed consumption (FC) of SCWL chicks fed diets containing blood meal supplemented with isoleucine are presented in Table 2. On average, the amount of feed consumed weekly throughout the 10 week period by birds fed diets containing $100 \%$ blood meal (BM) was about 19\% lower than that of birds fed the corn-soy control diet. With the exception of 1 and 5 weeks of age (WOA), the SCWL birds that were fed diets comprising $50 \%$ soybean meal and $50 \%$ blood meal (SMBM) consumed on average $6 \%$ less feed than the birds fed the con-soy control diet. During the 10 week study period, birds fed diets containing 50\% alfalfa meal and $50 \%$ blood meal (AMBM) consumed about $5 \%$ less 
Table 2. Feed consumption of Single Comb White Leghorn chicks ${ }^{1}$ fed diets containing blood meal supplemented with isoleucine from day-old to ten weeks of age

\begin{tabular}{|c|c|c|c|c|c|c|c|c|c|c|c|}
\hline Age (weeks) & 1 & 2 & 3 & 4 & 5 & 6 & 7 & 8 & 9 & 10 & Total $^{2}$ \\
\hline & & & & & 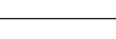 & (g/bird) & & & & & \\
\hline \multicolumn{12}{|c|}{ Dietary Treatment ${ }^{3}$} \\
\hline Corn-soy & $55.7^{\mathrm{a}}$ & $91.6^{\mathrm{a}}$ & $119.8^{\mathrm{a}}$ & $166.9^{\mathrm{a}}$ & $184.6^{\mathrm{b}}$ & $249.4^{\mathrm{a}}$ & $259.5^{\mathrm{a}}$ & $347.7^{\mathrm{a}}$ & $312.5^{\mathrm{a}}$ & $332.8^{\mathrm{a}}$ & $2,176.2^{\mathrm{a}}$ \\
\hline $\mathrm{BM}$ & $49.5^{c}$ & $67.6^{\mathrm{d}}$ & $100.0^{\mathrm{d}}$ & $131.3^{\mathrm{d}}$ & $166.6^{\mathrm{d}}$ & $210.9^{c}$ & $220.2^{\mathrm{d}}$ & $292.5^{\mathrm{d}}$ & $281.0^{\mathrm{c}}$ & $308.6^{\mathrm{c}}$ & $1,828.2^{\mathrm{d}}$ \\
\hline SMBM & $55.4^{\mathrm{a}}$ & $85.7^{\mathrm{b}}$ & $111.8^{\mathrm{b}}$ & $159.4^{\mathrm{b}}$ & $190.0^{\mathrm{a}}$ & $233.2^{\mathrm{b}}$ & $238.9^{\mathrm{b}}$ & $337.8^{\mathrm{b}}$ & $291.1^{\mathrm{b}}$ & $327.2^{\mathrm{b}}$ & $2,030.5^{\mathrm{b}}$ \\
\hline AMBM & $54.6^{\mathrm{b}}$ & $82.5^{\mathrm{c}}$ & $107.0^{c}$ & $138.7^{\mathrm{c}}$ & $172.5^{\mathrm{c}}$ & $203.2^{\mathrm{d}}$ & $222.8^{\mathrm{c}}$ & $317.1^{\mathrm{c}}$ & $271.3^{\mathrm{d}}$ & $304.4^{\mathrm{d}}$ & $1,874.2^{\mathrm{c}}$ \\
\hline PSEM $^{4}$ & 0.22 & 0.22 & 0.47 & 0.40 & 0.58 & 0.87 & 0.70 & 0.95 & 0.70 & 1.31 & 6.42 \\
\hline Probability & 0.001 & 0.001 & 0.001 & 0.001 & 0.001 & 0.001 & 0.001 & 0.001 & 0.001 & 0.001 & 0.001 \\
\hline
\end{tabular}

a,b,c,d Means within columns with no common superscript differ significantly $(P<0.05)$.

${ }^{1} \mathrm{~N}=120$ birds/treatment.

${ }^{2}$ Total feed consumed over 10 week period.

${ }^{3}$ Treatments $=$ Corn-soy $($ Control); Corn $+100 \%$ Blood meal $(\mathrm{BM})$; Corn $+50 \%$ Soybean meal $+50 \%$ Blood meal $(\mathrm{SMBM}) ; \mathrm{Corn}+50 \%$ Alfalfa meal $+50 \%$ Blood meal (AMBM).

${ }^{4}$ Pooled Standard Error of Mean.

than birds fed the corn-soy control diet. At 6, 9 and 10 WOA, AMBM birds consumed significantly less $(P<$ 0.05 ) feed than other treatment groups. In most part, inclusion of blood meal in diets of SCWL birds significantly decreased their feed consumption such that cornsoy control $>$ SMBM $>$ AMBM $>$ BM.

The lower feed consumption of birds fed diets containing blood meal may be due to poor palatability of the blood meal. Inclusion of blood meal in animal rations has been reported to be associated with poor palatability of feed (Grant and Haddad, 1998). In previous studies, DeRouchey et al. (2002) evaluated blood meal in diets of swine and observed that palatability became more of a determining factor in total feed consumption. The decrease in feed consumption of the SCWL chicks fed diets containing blood meal was also associated with a decrease in the consumption of crude protein (CP) and metabolizable energy (ME) as shown in Table 3 and 4, respectively. Mean CP consumption of birds fed diets containing blood meal was significantly $(P<0.05)$ lower than that of birds fed the corn-soy control diet such that Corn-soy $>$ SMBM $>$ AMBM $>$ BM. The average $\mathrm{CP}$ consumption of birds fed the corn-soy diet was about 19, 16 and $7 \%$ higher than that of birds fed the BM, AMBM and SMBM diets, respectively. Likewise, mean ME consumption of birds fed diets containing blood meal was significantly $(P<$ 0.05 ) lower than that of birds fed the corn-soy control diet such that Corn-soy $>$ SMBM $>$ AMBM $>$ BM. The mean ME consumption of birds fed the corn-soy diet was about 19,16 and $9 \%$ higher than that of birds fed the BM, AMBM and SMBM diets, respectively.

Mean body weight gains (BWG) of SCWL chicks fed diets containing blood meal supplemented with isoleucine are presented in Table 5. With the exception of 2, 4 and 8 WOA, the BWG of birds fed the control diet and those fed the SMBM diets were not different, however, they were significantly higher $(P<0.05)$ than those of bird fed the $\mathrm{BM}$ and AMBM diets at 1 to 8 WOA. At 2 and 4 WOA, birds on the control diet exhibited higher BWG than those on SMBM diet whereas at 8 weeks of age birds on the SMBM diet had higher BWG than those on the corn-soy control diet. The BWG of birds fed the AMBM were higher $(P<0.05)$ than those of birds on BM except at 6, 9 and 10 WOA where birds on BM had higher BWG than those on AMBM diets. These observations may suggest that SCWL birds may tolerate BM as a protein source as they get older. Overall, the SCWL chicks fed the corn-soy control diet were about 13 and $12 \%$ heavier than those fed the BM and AMBM diets, respectively. Although incorporating both soybean meal and blood meal as protein source in diets of SCWL chicks does not seem to have detrimental effect on BWG of these birds, incorporation of only blood meal or blood meal together with alfalfa meal seem to suppress BWG of the SCWL chicks. The lower BWG of birds fed the BM and AMBM may be attributed to depressed feed consumption of these birds (Table 2) which may also be associated with decrease in $\mathrm{CP}$ and $\mathrm{ME}$ consumption (Table 3 and 4, respectively). As reported earlier the lower feed consumption in these birds may be attributed to poor palatability of blood meal (Grant and Haddad, 1998) which ultimately translates to lower BWG and overall growth performance. Other reports that were in agreement with these observations (Kats et al., 1994) showed a decrease in average daily gain that was associated with increasing levels of blood meal in rations of swine at later stages of development. Regardless of dietary treatment, body weight gain was not linear and varied from week to week. For example, the body weight gain of experimental birds at 6 WOA was greater than at 7 WOA, but less than 8 WOA. The 8 week body weight gain was greater than 9 week body weight gain. This body weight gain pattern is also in agreement with previous reports (Aerts et al., 2003 and Ayanwale and Eya 2006; Nahashon et al., 2006). Body weight gains at any given period, especially during the accelerated growth phase will tend to vary from one period to another because the magnitude of growth spasms vary from time to time as observed during weeks $6,7,8,9$ and 10 (Table 5 of this 
Table 3. Crude protein consumption of single comb white leghorn chicks ${ }^{1}$ fed diets containing blood meal supplemented with isoleucine from hatch to ten weeks of age

\begin{tabular}{|c|c|c|c|c|c|c|c|c|c|c|c|}
\hline Age (weeks) & 1 & 2 & 3 & 4 & 5 & 6 & 7 & 8 & 9 & 10 & Total $^{2}$ \\
\hline & & & & & 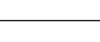 & (g/bird) & & & & & \\
\hline \multicolumn{12}{|c|}{ Dietary Treatment ${ }^{3}$} \\
\hline Con-Soy & $11.19^{\mathrm{a}}$ & $18.40^{\mathrm{a}}$ & $24.05^{\mathrm{a}}$ & $33.50^{\mathrm{a}}$ & $37.07^{\mathrm{b}}$ & $50.08^{\mathrm{a}}$ & $52.10^{\mathrm{a}}$ & $69.82^{\mathrm{a}}$ & $62.75^{\mathrm{a}}$ & $66.83^{\mathrm{a}}$ & $436.98^{a}$ \\
\hline $\mathrm{BM}$ & $9.91^{\mathrm{d}}$ & $13.55^{\mathrm{d}}$ & $20.02^{\mathrm{d}}$ & $26.31^{\mathrm{d}}$ & $33.37^{\mathrm{d}}$ & $42.24^{\mathrm{c}}$ & $44.11^{\mathrm{d}}$ & $58.59^{\mathrm{d}}$ & $56.28^{\mathrm{c}}$ & $61.82^{\mathrm{c}}$ & $366.19^{\mathrm{d}}$ \\
\hline SMBM & $11.09^{\mathrm{b}}$ & $17.15^{\mathrm{b}}$ & $22.37^{\mathrm{b}}$ & $31.90^{\mathrm{b}}$ & $38.03^{\mathrm{a}}$ & $46.67^{\mathrm{b}}$ & $47.80^{\mathrm{b}}$ & $67.59^{\mathrm{b}}$ & $58.26^{\mathrm{b}}$ & $65.46^{\mathrm{b}}$ & $406.31^{\mathrm{b}}$ \\
\hline AMBM & $10.93^{\mathrm{c}}$ & $16.51^{\mathrm{c}}$ & $21.41^{\mathrm{c}}$ & $27.76^{\mathrm{c}}$ & $34.51^{\mathrm{c}}$ & $40.66^{\mathrm{d}}$ & $44.58^{c}$ & $63.45^{\mathrm{c}}$ & $54.29^{d}$ & $60.92^{\mathrm{d}}$ & $375.02^{\mathrm{c}}$ \\
\hline PSEM $^{4}$ & 0.22 & 0.22 & 0.47 & 0.40 & 0.58 & 0.87 & 0.70 & 0.95 & 0.70 & 1.31 & 6.42 \\
\hline Probability & 0.001 & 0.001 & 0.001 & 0.001 & 0.001 & 0.001 & 0.001 & 0.001 & 0.001 & 0.001 & 0.001 \\
\hline
\end{tabular}

a,b, c, d Means within columns with no common superscript differ significantly $(P<0.05)$.

${ }^{1} \mathrm{~N}=120$ birds/treatment.

${ }^{2}$ Total crude protein consumed for the 10 week study period.

${ }^{3}$ Treatments $=$ Corn-soy $($ Control); Corn $+100 \%$ Blood meal $(\mathrm{BM})$; Corn $+50 \%$ Soybean meal $+50 \%$ Blood meal $(\mathrm{SMBM}) ; \mathrm{Corn}+50 \%$ Alfalfa meal $+50 \%$ Blood meal (AMBM).

${ }^{4}$ Pooled Standard Error of Mean.

Table 4. Metabolizable energy consumption of single comb white leghorn chicks ${ }^{1}$ fed diets containing blood meal supplemented with isoleucine from hatch to ten weeks of age

\begin{tabular}{|c|c|c|c|c|c|c|c|c|c|c|c|}
\hline Age (weeks) & 1 & 2 & 3 & 4 & 5 & 6 & 7 & 8 & 9 & 10 & Total $^{2}$ \\
\hline & & & & & & (kcal/bird) & & & & & \\
\hline \multicolumn{12}{|c|}{ Dietary Treatment $\mathrm{t}^{3}$} \\
\hline Con-Soy & $161.6^{\mathrm{a}}$ & $265.7^{\mathrm{a}}$ & $347.3^{\mathrm{a}}$ & $483.9^{\mathrm{a}}$ & $535.4^{\mathrm{b}}$ & $723.3^{\mathrm{a}}$ & $752.5^{\mathrm{a}}$ & $1008.4^{\mathrm{a}}$ & $906.2^{\mathrm{a}}$ & $965.8^{\mathrm{a}}$ & $6311.0^{\mathrm{a}}$ \\
\hline $\mathrm{BM}$ & $143.4^{\mathrm{c}}$ & $196.1^{\mathrm{c}}$ & $289.9^{c}$ & $380.7^{\mathrm{d}}$ & $483.2^{\mathrm{d}}$ & $611.5^{\mathrm{c}}$ & $638.7^{\mathrm{c}}$ & $848.3^{\mathrm{d}}$ & $814.8^{c}$ & $895.0^{\mathrm{b}}$ & $5301.8^{d}$ \\
\hline SMBM & $160.7^{\mathrm{a}}$ & $248.5^{\mathrm{b}}$ & $324.2^{\mathrm{d}}$ & $462.4^{\mathrm{b}}$ & $551.9^{\mathrm{a}}$ & $676.4^{\mathrm{b}}$ & $692.8^{\mathrm{b}}$ & $979.5^{\mathrm{b}}$ & $844.3^{\mathrm{b}}$ & $848.9^{c}$ & $5789.6^{\mathrm{b}}$ \\
\hline AMBM & $158.5^{\mathrm{a}}$ & $239.5^{\mathrm{b}}$ & $310.2^{\mathrm{c}}$ & $402.3^{\mathrm{c}}$ & $500.2^{\mathrm{c}}$ & $589.3^{\mathrm{d}}$ & $646.2^{\mathrm{c}}$ & $919.5^{\mathrm{c}}$ & $786.8^{\mathrm{d}}$ & $882.9^{\mathrm{b}}$ & $5435.1^{\mathrm{c}}$ \\
\hline PSEM $^{4}$ & 2.56 & 3.29 & 3.87 & 4.93 & 5.33 & 5.48 & 5.29 & 6.37 & 7.14 & 7.62 & 17.81 \\
\hline Probability & 0.001 & 0.001 & 0.001 & 0.001 & 0.001 & 0.001 & 0.001 & 0.001 & 0.001 & 0.001 & 0.001 \\
\hline
\end{tabular}

${ }^{\mathrm{a}, \mathrm{b}, \mathrm{c}, \mathrm{d}}$ Means within columns with no common superscript differ significantly $(P<0.05)$.

${ }^{1} \mathrm{~N}=120$ birds/treatment.

${ }^{2}$ Total metabolizable energy consumed for the 10 week study period.

${ }^{3}$ Treatments $=$ Corn-soy $($ Control $) ;$ Corn $+100 \%$ Blood meal $(\mathrm{BM})$; Corn $+50 \%$ Soybean meal $+50 \%$ Blood meal $(\mathrm{SMBM}) ; \mathrm{Corn}+50 \%$ Alfalfa meal $+50 \%$ Blood meal (AMBM).

${ }^{4}$ Pooled Standard Error of Mean.

report).

Feed conversion ratios (FCR) of SCWL chicks fed diets containing blood meal supplemented with isoleucine are presented in Table 6 . On average, over the 10 week study period, there were no significant differences $(P>$ $0.05)$ in average FCR among the birds fed the control, $\mathrm{BM}$ and AMBM diets. At 4 WOA differences in FCR among all dietary treatments were not significant $(P>$ 0.05). However, birds on corn-soy control and SMBM diets exhibited significantly lower $(P<0.05)$ FCR than other dietary treatments at 1 to 3 WOA. At 5, 6 and 8 to 10 WOA, birds fed the BM diet had significantly lower $(P$ $<0.05)$ FCR than those fed the corn-soy control diet. This observation is consistent with the observation on BWG (Table 5) that the SCWL birds tend to tolerate the dietary blood meal as they advance in age. With the exception of 1, 7 and 8 WOA, mean differences in FCR of birds on the BM were not different from those of birds on AMBM diets. At 1, 7 and 8 WOA mean FCR of birds on the AMBM were significantly lower $(P<0.05)$ than that of birds on the BM diet. Although FCR were not significantly different $(P>0.05)$ between birds fed control, $\mathrm{BM}$ and $\mathrm{AMBM}$ diets, the corresponding $\mathrm{FC}$ and BWG data (Tables 2 and 5, respectively) raises questions of the suitability of these diets for birds designated for future egg production.

The mean shank length (SL) of SCWL chickens fed diets containing blood meal and supplemented with isoleucine are presented in Table 7. Mean shank length of birds fed the corn-soy control diet was 6 to $8 \%$ higher ( $P$ $<0.05)$ than that of birds fed the BM diet at 6 to 10 WOA. With the exception of 6 WOA where differences in shank length were not significant, birds on AMBM and SMBM exhibited higher mean shank length than those on the BM diet. On the other hand, the shank length of SCWL birds that were fed the SMBM were not different $(P>0.05)$ from those of birds fed the AMBM diet at 6 to 10 WOA. Measurement of shank length provides a useful tool for evaluating frame development which is an important aspect of pullet quality at an early age. The measure- 
Table 5. Body weight gains of Single Comb White Leghorn chicks ${ }^{1}$ fed diets containing blood meal supplemented with isoleucine from day-old to ten weeks of age

\begin{tabular}{|c|c|c|c|c|c|c|c|c|c|c|c|}
\hline Age (weeks) & 1 & 2 & 3 & 4 & 5 & 6 & 7 & 8 & 9 & 10 & Total $^{2}$ \\
\hline & & & & & 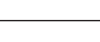 & (g/bird) & & & & & \\
\hline \multicolumn{12}{|c|}{ Dietary Treatment ${ }^{3}$} \\
\hline Corn-soy & $29.8^{\mathrm{a}}$ & $48.5^{\mathrm{a}}$ & $48.9^{\mathrm{a}}$ & $65.2^{\mathrm{a}}$ & $54.1^{\mathrm{d}}$ & $87.8^{\mathrm{a}}$ & $72.6^{\mathrm{a}}$ & $120.0^{\mathrm{b}}$ & $61.4^{\mathrm{a}}$ & $82.0^{\mathrm{b}}$ & $670^{\mathrm{a}}$ \\
\hline $\mathrm{BM}$ & $22.6^{\mathrm{c}}$ & $28.6^{\mathrm{d}}$ & $37.4^{\mathrm{c}}$ & $50.1^{\mathrm{d}}$ & $55.9^{c}$ & $73.6^{\mathrm{b}}$ & $62.0^{c}$ & $109.5^{\mathrm{c}}$ & $62.7^{\mathrm{a}}$ & $89.4^{\mathrm{a}}$ & $592^{\mathrm{c}}$ \\
\hline SMBM & $30.1^{\mathrm{a}}$ & $41.1^{\mathrm{b}}$ & $51.1^{\mathrm{a}}$ & $60.7^{b}$ & $68.7^{\mathrm{a}}$ & $86.0^{\mathrm{a}}$ & $75.3^{\mathrm{a}}$ & $126.2^{\mathrm{a}}$ & $58.6^{\mathrm{a}}$ & $79.6^{\mathrm{b}}$ & $677^{\mathrm{a}}$ \\
\hline AMBM & $27.0^{\mathrm{b}}$ & $34.2^{c}$ & $40.7^{b}$ & $54.9^{c}$ & $59.8^{\mathrm{b}}$ & $64.1^{c}$ & $66.3^{\mathrm{b}}$ & $124.8^{\mathrm{a}}$ & $53.7^{\mathrm{b}}$ & $82.9^{b}$ & $608^{\mathrm{b}}$ \\
\hline PSEM $^{4}$ & 0.52 & 0.75 & 0.92 & 1.10 & 1.03 & 1.25 & 1.17 & 1.49 & 1.27 & 1.49 & 2.10 \\
\hline Probability & 0.001 & 0.001 & 0.001 & 0.001 & 0.001 & 0.001 & 0.001 & 0.001 & 0.001 & 0.001 & 0.001 \\
\hline
\end{tabular}

a,b,c,d Means within columns with no common superscript differ significantly $(P<0.05)$.

${ }^{1} \mathrm{~N}=120$ birds/treatment.

${ }^{2}$ Total body weight gain for the ten week study period.

${ }^{3}$ Treatments $=$ Corn-soy $($ Control $) ;$ Corn $+100 \%$ Blood meal $(\mathrm{BM}) ;$ Corn $+50 \%$ Soybean meal $+50 \%$ Blood meal $(\mathrm{SMBM}) ; \mathrm{Corn}+50 \%$ Alfalfa meal $+50 \%$ Blood meal (AMBM).

${ }^{4}$ Pooled Standard Error of Mean.

Table 6. Feed conversion ratios for Single Comb White Leghorn chicks ${ }^{1}$ fed diets containing blood meal supplemented with isoleucine from day-old to ten weeks of age

\begin{tabular}{|c|c|c|c|c|c|c|c|c|c|c|c|}
\hline Age (weeks) & 1 & 2 & 3 & 4 & 5 & 6 & 7 & 8 & 9 & 10 & Average $^{2}$ \\
\hline & & & & & $(\mathrm{g} \mathrm{f}$ & /g weig & gain) & & & & 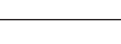 \\
\hline \multicolumn{12}{|c|}{ Dietary Treatment ${ }^{3}$} \\
\hline Corn-soy & $1.95^{\mathrm{c}}$ & $1.93^{c}$ & $2.49^{\mathrm{b}}$ & 2.63 & $3.53^{\mathrm{a}}$ & $2.87^{\mathrm{b}}$ & $3.61^{\mathrm{a}}$ & $2.94^{\mathrm{a}}$ & $5.26^{\mathrm{a}}$ & $4.16^{\mathrm{a}}$ & $3.14^{\mathrm{a}}$ \\
\hline $\mathrm{BM}$ & $2.30^{\mathrm{a}}$ & $2.72^{\mathrm{a}}$ & $2.90^{\mathrm{a}}$ & 2.80 & $3.12^{\mathrm{b}}$ & $2.98^{\mathrm{b}}$ & $3.69^{\mathrm{a}}$ & $2.77^{\mathrm{b}}$ & $4.63^{\mathrm{b}}$ & $3.55^{\mathrm{b}}$ & $3.15^{\mathrm{a}}$ \\
\hline SMBM & $1.91^{\mathrm{c}}$ & $2.15^{\mathrm{c}}$ & $2.27^{\mathrm{c}}$ & 2.73 & $2.83^{c}$ & $2.61^{\mathrm{c}}$ & $3.20^{\mathrm{c}}$ & $2.72^{\mathrm{b}}$ & $5.30^{\mathrm{a}}$ & $4.30^{\mathrm{a}}$ & $3.00^{\mathrm{b}}$ \\
\hline AMBM & $2.14^{\mathrm{b}}$ & $2.64^{\mathrm{a}}$ & $2.78^{\mathrm{a}}$ & 2.65 & $3.02^{\mathrm{b}}$ & $3.31^{\mathrm{a}}$ & $3.43^{\mathrm{b}}$ & $2.56^{\mathrm{c}}$ & $5.33^{\mathrm{a}}$ & $3.74^{\mathrm{b}}$ & $3.16^{\mathrm{a}}$ \\
\hline PSEM $^{4}$ & 0.04 & 0.07 & 0.06 & 0.06 & 0.06 & 0.05 & 0.05 & 0.04 & 0.11 & 0.07 & 0.06 \\
\hline Probability & 0.001 & 0.001 & 0.001 & 0.001 & 0.001 & 0.001 & 0.001 & 0.001 & 0.001 & 0.001 & 0.001 \\
\hline
\end{tabular}

${ }_{\mathrm{a}, \mathrm{b}, \mathrm{c}}$ Means within columns with no common superscript differ significantly $(P<0.05)$.

${ }^{1} \mathrm{~N}=120$ birds/treatment.

${ }^{2}$ Average of ten week study period.

${ }^{3}$ Treatments $=$ Corn-soy $($ Control); Corn $+100 \%$ Blood meal $(\mathrm{BM}) ;$ Corn $+50 \%$ Soybean meal $+50 \%$ Blood meal $(\mathrm{SMBM}) ;$ Corn $+50 \%$ Alfalfa meal $+50 \%$ Blood meal (AMBM).

${ }^{4}$ Pooled Standard Error of Mean.

Table 7. Shank lengths of Single Comb White Leghorn chicks ${ }^{1}$ fed diets containing blood meal supplemented with isoleucine from day-old to ten weeks of age

\begin{tabular}{lcccc}
\hline \hline \multicolumn{1}{c}{ Age (weeks) } & 6 & 8 & 9 & 10 \\
\cline { 2 - 5 } & \multicolumn{5}{c}{$(\mathrm{mm} /$ bird) } & \\
\cline { 2 - 5 } Dietary Treatment $^{2}$ & & & \\
Corn-Soy & $66.55^{\mathrm{a}}$ & $78.49^{\mathrm{a}}$ & $81.53^{\mathrm{a}}$ & $87.88^{\mathrm{a}}$ \\
$\mathrm{BM}$ & $62.74^{\mathrm{b}}$ & $72.64^{\mathrm{c}}$ & $77.72^{\mathrm{b}}$ & $84.07^{\mathrm{b}}$ \\
SMBM & $65.79^{\mathrm{a}}$ & $77.47^{\mathrm{ab}}$ & $81.79^{\mathrm{a}}$ & $88.39^{\mathrm{a}}$ \\
AMBM & $64.26^{\mathrm{ab}}$ & $75.95^{\mathrm{b}}$ & $80.77^{\mathrm{a}}$ & $88.65^{\mathrm{a}}$ \\
PSEM $^{3}$ & 0.76 & 0.76 & 0.76 & 0.76 \\
Probability & 0.001 & 0.001 & 0.001 & 0.001 \\
\hline
\end{tabular}

a,b,c Means within columns with no common superscript differ significantly $(P<0.05)$.

${ }^{1} \mathrm{~N}=120$ birds/treatment.

${ }^{2}$ Treatments $=$ Corn-soy $($ Control); Corn $+100 \%$ Blood meal (BM); Corn $+50 \%$ Soybean meal $+50 \%$ Blood meal (SMBM); Corn + $50 \%$ Alfalfa meal $+50 \%$ Blood meal (AMBM).

${ }^{3}$ Pooled Standard Error of Mean. ment is usually taken between 4 and 10 WOA because the skeleton is practically fully developed by 10 WOA (Bell, 2002).

The mean organ weights of SCWL chickens fed diets containing blood meal and supplemented with isoleucine at hatch to 10 WOA are presented in Table 8. Differences in weight of heart, lungs and spleen of birds fed the corn-soy control diet and those fed diets containing BM were not significant $(P<0.05)$. However, the weight of small intestine and kidneys of birds on the corn-soy control diet was significantly higher $(P<0.05)$ than that of birds fed diets containing BM. The weight of the liver of birds receiving the $\mathrm{BM}$ diet was about $18 \%$ higher than that of bird on the corn-soy control diet. The weight of the liver of the birds on BM diet was also significantly higher than that of birds fed the SMBM and AMBM diets as well. It is possible that this was an indirect response to the poor palatability that led to lower consumption of diets that contained blood meal (Table 2). The lower feed consumption was also associated with decreased consump- 
Tyus II et al: : Blood Meal for White Leghorn Chicks

Table 8. Organ weights and cumulative mortality of Single Comb White Leghorn chicks ${ }^{1}$ fed diets containing blood meal supplemented with isoleucine from day-old to ten weeks of age

\begin{tabular}{|c|c|c|c|c|c|c|c|c|}
\hline Organ & Heart & Kidney & Liver & Lungs & Pancreas & Small Intestine & Spleen & Mortality $^{2}$ \\
\hline & & & 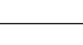 & $00 \mathrm{~g}$ bod & 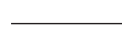 & $S_{1+2}$ & 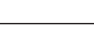 & $-(\%)-$ \\
\hline \multicolumn{9}{|l|}{ Dietary Treatment ${ }^{3}$} \\
\hline Con-soy & 0.53 & $0.80^{\mathrm{a}}$ & $2.64^{\mathrm{b}}$ & 0.84 & $0.35^{\mathrm{a}}$ & $6.41^{\mathrm{a}}$ & 0.25 & $0.83^{\mathrm{c}}$ \\
\hline $\mathrm{BM}$ & 0.60 & $0.70^{\mathrm{ab}}$ & $3.12^{\mathrm{a}}$ & 0.75 & $0.30^{\mathrm{b}}$ & $4.41^{\mathrm{b}}$ & 0.25 & $5.83^{\mathrm{a}}$ \\
\hline SMBM & 0.51 & $0.60^{\mathrm{b}}$ & $1.96^{\mathrm{c}}$ & 0.71 & $0.31^{\mathrm{ab}}$ & $4.42^{\mathrm{b}}$ & 0.24 & $4.17^{\mathrm{b}}$ \\
\hline AMBM & 0.58 & $0.63^{\mathrm{b}}$ & $2.67^{\mathrm{b}}$ & 0.75 & $0.32^{\mathrm{a}}$ & $5.01^{\mathrm{b}}$ & 0.24 & $3.33^{\mathrm{b}}$ \\
\hline PSEM $^{4}$ & 0.03 & 0.05 & 0.18 & 0.05 & 0.02 & 0.30 & 0.02 & 0.34 \\
\hline Probability & 0.001 & 0.001 & 0.001 & 0.001 & 0.001 & 0.001 & 0.001 & 0.002 \\
\hline
\end{tabular}

a,b,c,d Means within columns with no common superscript differ significantly $(P<0.05)$.

${ }^{1} \mathrm{~N}=120$ birds/treatment.

${ }^{2}$ Cumulative for the entire 10 week study period.

${ }^{3}$ Treatments $=$ Corn-soy $($ Control); Corn $+100 \%$ Blood meal $(\mathrm{BM}) ;$ Corn $+50 \%$ Soybean meal $+50 \%$ Blood meal (SMBM); Corn $+50 \%$ Alfalfa meal $+50 \%$ Blood meal (AMBM).

${ }^{4}$ Pooled Standard Error of Mean.

tion of $\mathrm{CP}$ and $\mathrm{ME}$ (Table 3 and 4, respectively). The liver is the predominant site of lipogenesis and synthesis of other essential body constituents or building blocks in birds (O'Hea and Leveille, 1969), hence one feasible response would be an over-activity of the liver to synthesize these constituents, such as fatty acids, from the available nutrients in instances where nutrients are deficient. Various supply organs such as liver, pancreas, heart, small intestine and lungs are responsible for making energy available for growth process (Katanbaf et al., 1988). These supply organs are necessary in order to fill the nutritional demand of the growing bird.

The mean weight of the pancreas of birds fed BM diets was significantly lower $(P<0.05)$ than in other treatment groups. Also the mean weight of intestine was higher in the birds fed the corn-soy control diet than those fed diets containing blood meal. This could be, both directly and indirectly, related to feed consumption and body weight gain as well. Directly, in the sense that, the amount of nutrients an animal consumes is directly proportional to the amount of nutrients that will possibly be available for growth and development of body tissues. But also indirectly, in that, the less an animal consumes, the smaller the role of the exocrine functions of pancreatic tissue. Digestive enzymes are synthesized and secreted in response to feed intake. Therefore, lowered feed consumption during the tissue developmental stage, could lead to lowered cytogenesis of cells that produce those enzymes. Nitsan et al. (1991) proposed that adaptation to exogenous feed was associated with increase in weight of the gastrointestinal tract and level of these digestive enzymes. This is consistent with our findings that the heavier birds had greater pancreatic and intestinal weights and also consumed more feed than their slow-growing counterparts. Thus the weight of the pancreas, a supply organ (Katanbaf et al., 1988) that is necessary to fulfill the nutritional demand of the rapidly growing birds may be associated with the higher body weight gain of the birds fed the corn-soy control diets as well as those fed the SMBM and AMBM diets. Burger et al. (1962) reported positive correlations between body weight gain and weight of individual organs in chickens. The mass of many organs alters in response to workload and this has been observed in the cardiac muscles (Morgan et al., 1980), the liver and kidney (Ferrell and Koong, 1986) and the small intestine (Ferrell et al., 1986). Nitsan et al. (1991) reported smaller heart weight for heavier birds; however, liver, proventriculus, gizzard and small intestine were higher for heavier birds irrespective of weights being expressed on an absolute basis or relative to body weight.

Percent mortality of SCWL chickens fed diets containing blood meal and supplemented with isoleucine at hatch to 10 WOA are presented in Table 8. Percent mortality of birds that were fed BM diet was significantly higher $(P<$ 0.05) than that of birds fed the control, SMBM and AMBM diets. The birds on the corn-soy control diets experienced the lowest mortality which was also significantly lower than that of bird fed the SMBM and AMBM diets. Differences in percent mortality of birds on SMBM and those on AMBM were not significant. The high mortality in birds that were fed the BM and also SMBM and AMBM diets may be associated with poor feed consumption, insufficiency of nutrients such as $\mathrm{CP}$ and $\mathrm{ME}$ and poor development of key metabolic organs of the SCWL birds.

Based on the conditions of this study, incorporating blood meal with supplemental isoleucine as single source of protein in diets of SCWL chicks may lead to a significantly reduction in feed consumption, growth rate, development of key metabolic organs, and increased mortality of these birds. However, substituting up to 50\% soybean meal with blood meal supplemented with isoleucine in corn-soy based diets seem to have no adverse effect on performance of SCWL chicks at hatch to 10 WOA. It is however worth noting that at early age (hatch to 5 WOA) birds tend to be more susceptible to adverse effects of blood meal in poultry rations. Partial substitution of BM with alfalfa meal (AMBM) improved feed 
consumption, BWG and FCR of the SCWL chicks. However, the improvement in performance of these birds on the AMBM diets was still lower than that of birds fed the corn-soy control and SMBM diets, especially at hatch to 5 WOA.

\section{Acknowledgments}

This study was funded through USDA Evans-Allens funds.

\section{References}

Aerts JM, Van Buggenhout S, Vranken E, Lippens M, Buyse J, Decuypere E and Berckmans D. Active control of the growth trajectory of broiler chickens based on online animal responses. Poultry Science, 82: 1853-1862. 2003.

Ayanwale, BA and Eya VE. Nutrition evaluation of cornflakes waste in diets of broilers. Pakistani Journal of Nutrition, 5: 485-489. 2006.

Bell DD. A model one million hen in-line egg production complex. In: Commercial Chicken Meat and Egg Production (Bell DD and Weaver WD eds.). pp 287-328. Cluwer Academic Publishers, The Netherlands. 2002.

Buddington RK, Buddington KK and Sunvold GD. Influence of fermentable fiber on small intestinal dimensions and transport of glucose and praline in dogs. American Journal of Veterinary Research, 60: 354-358. 1999.

Burnham D, Emmans GC and Gous RM. Isoleucine requirements of the chicken: the effect of excess leucine and valine on the response to isoleucine. British Poultry Science, 33: 71-87. 1992.

Burger RE, Lorenz FW and Gates CE. Relationships of organ weight to body weight. Poultry Science, 41: 1762-1773. 1962.

Coon CN. Feeding egg-type replacement pullets. In: Commercial Chicken Meat and Egg Production. (Bell DD and Weaver WD eds.). pp. 267-285. Cluwer Adademic Publishers, Dordrecht, The Netherlands. 2002.

Costa EF, Miller BR, Pesti GM, Bakalli RI and Ewing HP. Studies on feeding peanut meal as a protein source for broiler chickens. Poultry Science, 80: 306-313. 2001.

DeRouchey JM, Tokach MD, Nelssen JL, Goodband RD, Dritz SS, Woodworth JC and James BW. Comparison of spraydried blood meal and blood cells in diets for nursery pigs. Journal of Animal Science, 80: 2879-2886. 2002.

Donalson, LM., Kim WK, Hererra P, Woodward CL, Kubena LF, Nisbet DJ and Ricke SC. Combining a prebiotic with an alfalfa molting diets to increase in vitro fermentation by laying hens cecal bacteria. Poultry Science, 83: 1798 (Abstr.). 2004.

Ferrell CL and Koong KJ. Influence of plane of nutrition on body composition, organ size and energy utilization of spragueDawley rats. Journal of Nutrition, 116: 2525-2535. 1986.

Ferrell CL, Koong KJ and Nienaber JA. Effect of previous nutrition on body composition and maintenance energy cost of growing lambs. British Journal of Nutrition, 56: 595-605. 1986.

Garcia J, Carabaňo R, Perěz-Alba L and de Blas JC. Effect of fiber source on cecal fermentation and nitrogen recycled through cecotrophy in rabbits. Journal of Animal Science, 78: 638-646. 2000.

Grant RJ and Haddad SG. Effect of a Mixture of Feather and Blood Meals on Lactational Performance of Dairy Cows. Journal of Dairy Science, 81: 1358-1363. 1998.

Hale LL, Barber SJ, Corzo A and Kidd MT. Isoleucine needs of thirty- to forty-two-day-old female chickens: growth and carcass responses. Poultry Science, 83: 1986-1991. 2004.

Hoaglund CM, Thomas VM, Peterson MK and Knott RW. Effects of supplemental protein source and metabolizable energy intake on nutritional status in pregnant ewes. Journal of Animal Science, 70: 273-280. 1992.

Katanbaf MN, Jones DE, Dunnington EA, Gross WB and Siegel PB. Anatomical and physiological responses of early and late feathering broiler chicken to various feeding regimes. Archiv für Geflügelkunde, 52: 119-126. 1988.

Kats LJ, Nelssen JL, Tokach MD, Goodband RD, Weeded TL, Dritz SS, Hansen JA and Friesen KG. The effects of spraydried blood meal on the growth performance of the earlyweaned pig. Journal of Animal Science, 72: 2860-2869. 1994.

Kidd MT, Burnham DJ and Kerr BJ. Dietary isoleucine responses in male broiler chickens. British Poultry Science, 45: 67-75. 2004.

Kita K, Nagao K, Taneda N, Inagaki Y, Hirano K, Shibata T, Yaman MA., Conlon MA and Okumura J. Insulin-like growth factor binding protein-2 gene expression can be regulated by diet manipulation in several tissues of young chickens. Journal of Nutrition. 132: 145-151. 2002.

Klita PT, Mathison GW, Fenton TW and Hardin TW. Effect of alfalfa root saponins on digestive function in sheep. Journal of Animal Science, 74: 1144-1156. 1996.

Morgan HE, Chua BHL, Fuller EO and Siehl DH. Regulation of protein synthesis and breakdown during in vitro cardiac work. American Journal of Physiology, 238: E431-E437. 1980.

Nahashon, SN., Aggrey SE, Adefope A, Amenyenu A and Wright D. Growth characteristics of pearl gray Guinea fowl as predicted by the Richard's, Gompertz and Logistic Models. Poultry Science, 85: 359-363. 2006.

National Research Council. Nutrient Requirements of Poultry. National Academy Press, Washington, DC. 1994.

Nitsan Z, Ben-Avraham G, Zoref Z and Nir I. Growth and development of the digestive organs and some enzymes after hatching in broiler chickens. British Poultry Science, 32: 515-523. 1991.

O'Hea EK and Leveille GA. Lipid biosynthesis and transport in the domestic chick (Gallus domesticus). Comparative Biochemistry and Physiology, 30: 149-159. 1969.

Ponte PIP, Mendes I, Quaresma M, Aguiar MNM, Lemos JPC, Ferreira LMA, Soares MAC, Alfaia CM, Prates JAM and Fontes CMGA. Cholesterol levels and sensory characteristics of meat from broilers consuming moderate to high levels of alfalfa. Poultry Science, 83: 810-814. 2004.

Salvin JL, Nelson NL, McNamara EA and Cashmere K. Bowel function of healthy men consuming liquid diets with and without dietary fiber. Journal of Parenteral and Enteral Nutrition, 9: 317-321. 1985.

SAS Institute. SAS User's Guide: Statistics. Version 5 Edition, SAS Institute Inc., Cary, North Carolina. 2002.

Sindt MH, Stock RA, Klopfenstein TJ and Shain DH. Effect of protein source and grain type on finishing calf performance and ruminal metabolism. Journal of Animal Science, 71: 1047-1056. 1993.

Sibbald IR. Passage of feed through the adult rooster. Poultry Science, 58: 446-459. 1979.

Sterling KG, Costa EF, Henry MH, Pesti GM and Bakalli RI. Responses of broiler chickens to cottonseed- and soybean meal-based diets at several protein levels. Poultry Science, 81: 217-226. 2002. 